\title{
Analysis of Soil Transfer Function in Izmir Metropolitan Area, Turkey
}

\author{
Caglar Ozer ${ }^{1,2}$ \\ ${ }^{l}$ Division of Seismology, Department of Geophysics, Engineering Faculty, Dokuz Eylul University, Izmir, \\ Turkey,e-mail: caglar.ozer@deu.edu.tr \\ ${ }^{2}$ Division of Seismology, Department of Geophysics, Oltu Earth Sciences Faculty, Ataturk University, Erzurum, \\ Turkey,e-mail: caglarozer@atauni.edu.tr
}

\begin{abstract}
The soil transfer function of Izmir, one of the most seismically active regions in Turkey has been determined by using IzmirNET strong motion stations. We conducted Standard Spectral Ratio (SSR) method using five well-spread earthquakes $S$ - wave recording. These events have been selected with respect to azimuthal distribution for each and after that their spectrums were calculated considering some data processing condition. These stations spectrums have been divided by the reference station amplification which was selected as YMN and afterwards, standard spectral ratio of chosen earthquakes was shown as chart for each station. It has been determined that the earthquake effect can be increased 4-5 times depending on the distance, size and depth of earthquake in residential areas near URL, KSK, BYN and KON strong motion stations. Results also indicate that, big amplification was calculated on quaternary alluvial unit at low frequencies.
\end{abstract}

Keywords: Engineering Seismology, IzmirNET, Site effect, Standard spectral ratio

\section{Introduction}

Izmir, Turkey's third largest city in terms of population density has been the scene of many earthquakes throughout history. The city is surrounded by E-W extended faults associated with the extension of the N-S in the region and is growing rapidly on young Quaternary-Neogene sediments. It has also been reported that most of the destructive earthquakes occurred in the south of Izmir Bay and their depths are less than $30 \mathrm{~km}$. According to the kinematic fault plane results, it also indicates strike-slip faults and a small number of reverse faults in addition to the normal-slip faults. Non-monotype structure of the mechanism solutions is due to the heterogeneous structure of the western Anatolia crust [1]. A local seismic network (IzmirNET) [2] consisting of 16 strong ground motion earthquake stations in Izmir city center area was established with contributions of AFAD (Earthquake Department of the Disaster and Emergency Management Authority) in 2008 (Fig. 1). IzmirNET earthquake stations (Table 1) were built on four different geological units to surround the main tectonic elements that produce earthquakes, mostly in residential areas around the Bay (Fig. 1). The four main geological units that dominate Izmir Bay and its vicinity are; Quaternary old sediments Miocene sedimentary units, Miocene volcanic units and pre-Miocene base rocks [3-5]. In this study, local soil effects were investigated by Standard Spectral Ratio (SSR) technique using the amplitudes of S-components of earthquakes recorded by IzmirNET stations. The study area generally covers the area between $37.70^{\circ}$ and $39.20^{\circ} \mathrm{N}$ latitudes and $26.30^{\circ}-28.80^{\circ} \mathrm{E}$ longitudes.

Table-1: The location of local seismic network (IzmirNET)

\begin{tabular}{|c|c|c|}
\hline Station Code & Longitude $\left.^{(}{ }^{\circ}\right)$ & Latitude $\left(^{\circ}\right)$ \\
\hline BLC & 27.04 & 38.41 \\
\hline BOS & 27.09 & 38.46 \\
\hline BUC & 27.15 & 38.40 \\
\hline BYN & 27.16 & 38.45 \\
\hline BYR & 27.15 & 38.47 \\
\hline CMD & 27.19 & 38.43 \\
\hline GZL & 26.89 & 38.37 \\
\hline KON & 27.14 & 38.43 \\
\hline KSK & 27.11 & 38.45 \\
\hline KYN & 27.19 & 38.37 \\
\hline MNV & 27.21 & 38.47 \\
\hline MVS & 27.07 & 38.46 \\
\hline PNR & 27.25 & 38.42 \\
\hline URL & 26.77 & 38.32 \\
\hline YMN & 27.10 & 38.49 \\
\hline YSL & 27.10 & 38.37 \\
\hline DKL & 26.88 & 39.07 \\
\hline GZLY & 27.08 & 38.39 \\
\hline BRN & 27.22 & 38.45 \\
\hline
\end{tabular}




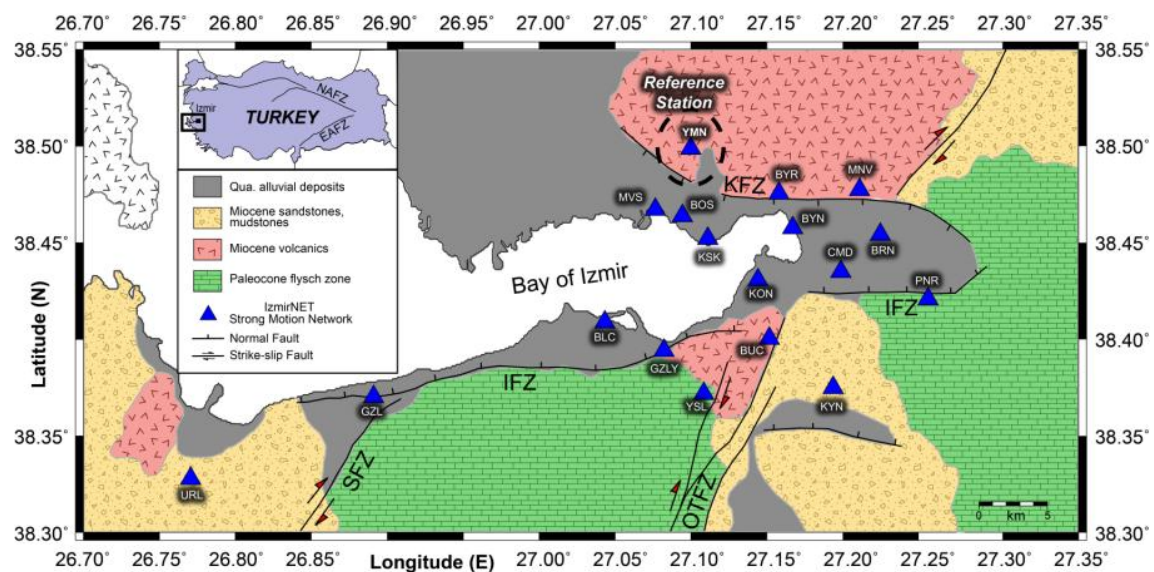

Fig. 1: Geological and principal tectonic characteristic map around Izmir, Turkey. Blue triangles symbolized the IzmirNET strong motion network. Station description was given at Table-1. EAFZ: East Anatolian Fault Zone, KFZ: Karsiyaka Fault Zone, NAFZ: North Anatolian Fault Zone, IFZ: Izmir Fault Zone, SFZ: Seferihisar Fault Zone, OTFZ: Orhanli-Tuzla Fault Zone) [compiled from 1,5-7]

The most important tectonic features affecting Izmir and its surrounding areas are Karsiyaka Fault Zone (KFZ), Izmir Fault Zone (IFZ), Seferihisar Fault Zone (SFZ) and Orhanli-Tuzla fault zone (OTFZ). SFZ extends in the southwest of Izmir between Izmir Bay and Guzelbahce in connection with the E-W extended IFZ. The length of SFZ is about $30 \mathrm{~km}$ and it is mostly located in Bornova Flysch and alluviums. OTFZ is located on the southwest of Izmir in the form of a NE-SW zone between Gaziemir and Doganbey. This fault, approximately $50 \mathrm{~km}$ long, has a left strike-slip fault and forms a tectonic contact between the Neogene age rock groups that are exposed between Bornova Flysch metamorphic rocks and Cumaovasi-Aegean Sea. IFZ is a normal dip-slip, E-W extended and $35 \mathrm{~km}$ long fault on the east of Izmir Bay. It can be said that the fault emerged after Miocene era according to the geological data. KFZ has the oblique-slip normal fault features with a E-W extension and a slope to the south [8].

Earthquake records symbolized the source effect, environmental effect and soil effect of all layers it passed below ground until it comes from the hypocenter to the station. Understanding these parameters provides important contributions to planning and engineering seismology studies to minimize earthquake damages. The determination of the soil effect, which is the main objective of this study, allows the necessary results to be obtained without waiting for an earthquake. In this study, the soil transfer function was determined by using earthquake records because of the reasons mentioned above.

\section{Data And Method}

Five earthquake data recorded by at least ten strong motion stations in different magnitudes and distances were used to determine soil characteristics (Fig.2). These earthquakes occurred between the dates 06.07.2015-06.02.2017 and their local magnitudes were determined to be larger than 4. The depth distribution of selected earthquakes is between 7 and $26 \mathrm{~km}$ (Table 2).

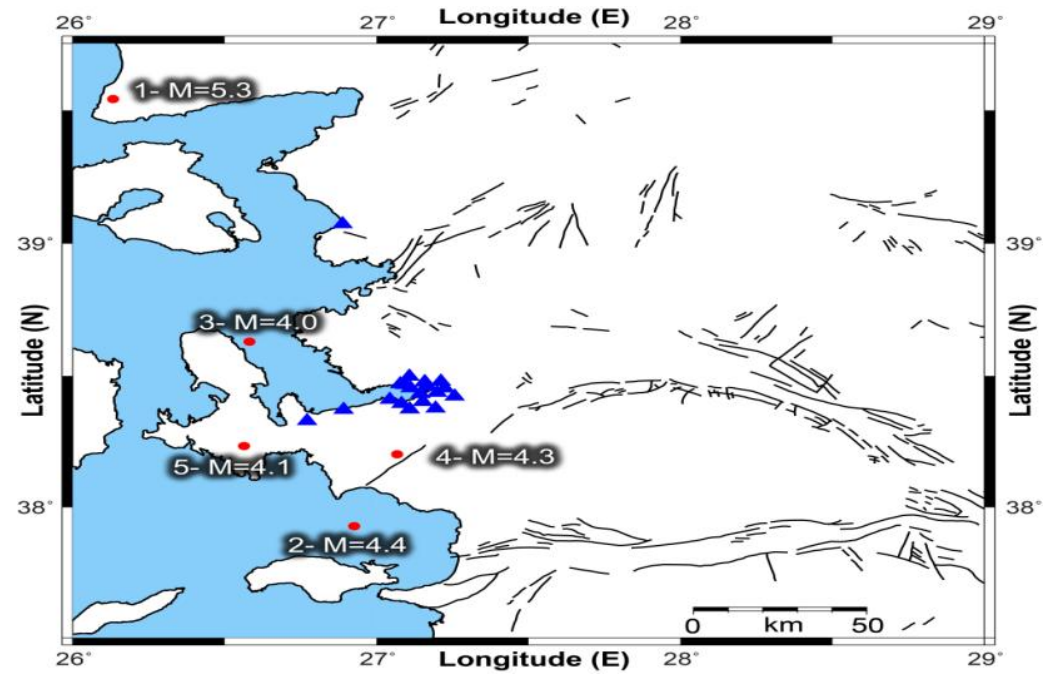

Fig. 2: Distribution of selected five earthquake locations and main tectonic features of western Anatolia. 
The SSR technique is a widely used method for the determination of the soil transfer function. The most important factor affecting the success of this method is to determine of the reference station. The YMN accelerometer based on Miocene volcanic among the IzmirNET strong motion stations located on four different geological units in general was chosen as the reference station for the SSR method (Fig. 3). The ratio of the spectrums of the earthquakes recorded by all stations in the frequency domain to the spectral spectrum recorded at the YMN station reflects the properties of the ground in which the station is located.

Table-2: Earthquake parameters of selected earthquakes

\begin{tabular}{|c|c|c|c|c|c|c|c|}
\hline No & Date & Time & Latitude & Longitude & Magnitude & Depth & Location \\
\hline $\mathbf{1}$ & $06 / 02 / 2017$ & $06: 51: 40$ & 39.5426 & 26.1325 & 5.3 & 26.1 & Canakkele-Ayvacik \\
\hline $\mathbf{2}$ & $17 / 10 / 2016$ & $01: 30: 32$ & 37.9275 & 26.9261 & 4.4 & 10.3 & Kusadasi Bay \\
\hline $\mathbf{3}$ & $19 / 12 / 2015$ & $11: 14: 56$ & 38.6303 & 26.5821 & 4.0 & 4.8 & Izmir-Karaburun \\
\hline $\mathbf{4}$ & $10 / 01 / 2015$ & $04: 32: 08$ & 38.2026 & 27.0678 & 4.3 & 7.8 & Izmir-Menderes \\
\hline $\mathbf{5}$ & $06 / 07 / 2015$ & $01: 03: 48$ & 38.234 & 26.5638 & 4.1 & 15.5 & Izmir-Urla \\
\hline
\end{tabular}

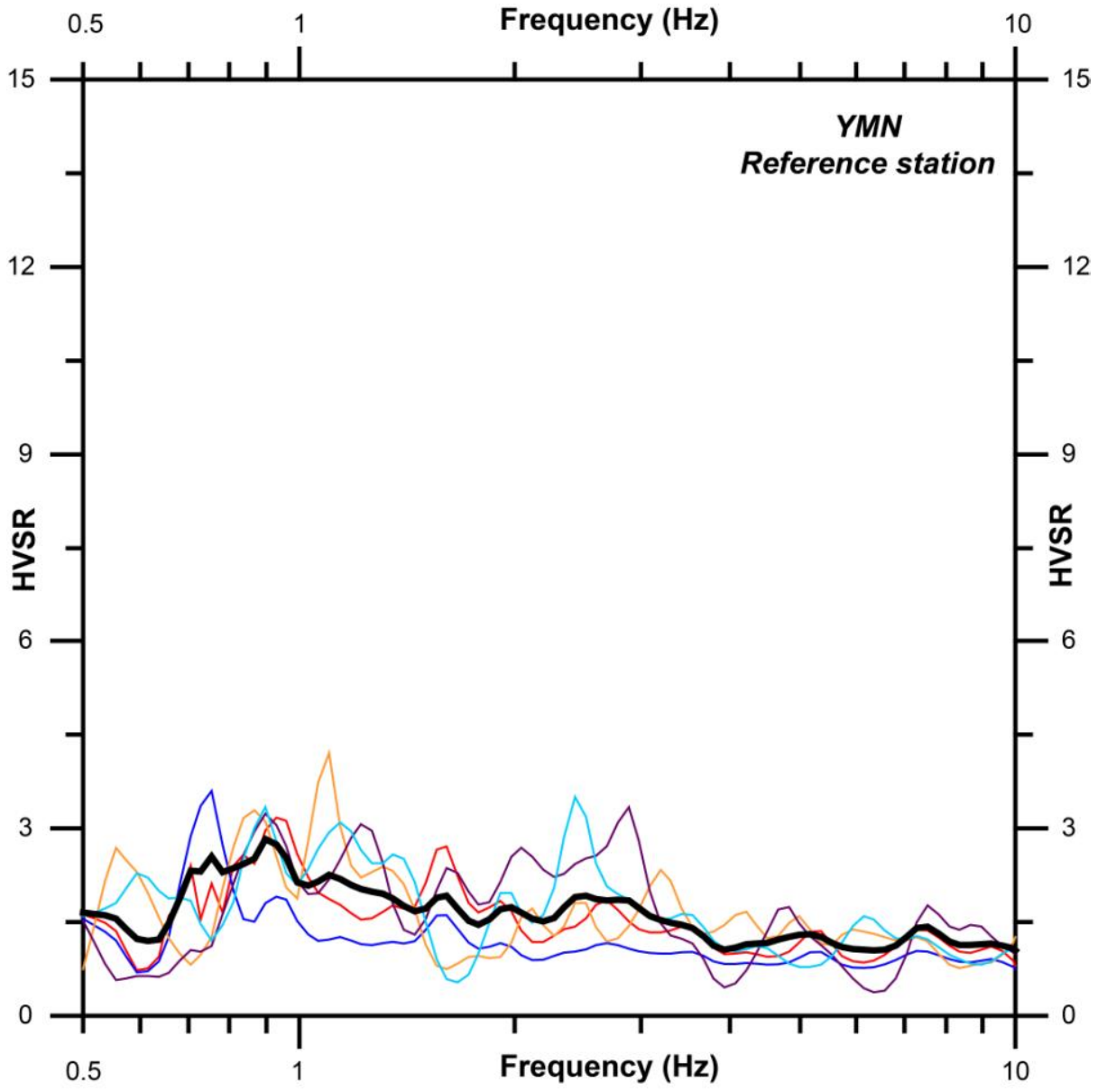

Fig. 3: Horizontal to vertical spectral ratio (HVSR) result to determinate amplification of Yamanlar (YMN) station. The thin black curve symbolized mean value of five earthquakes.

In summary, the ratio of the earthquake spectrum obtained on soft grounds to the reference station spectrum, which represents the solid ground in the region, forms the basis of the method. It is necessary to use the same earthquake and the same accelerometer when these analyzes are carried out. With this condition, the effect of station and source is eliminated. Data-processing phase was applied according to Sesame criteria [9] and software named GEOPSY $[9,10]$ was used in calculations. The first step in the data processing phase is to window (40 second) the highest amplitudes in the S-wave phase that are believed to contain the earthquake energy and calculate the Fourier amplitude spectrum. The Fourier transform was used to transfer the data from the time domain to the frequency domain, and the SSR spectrums were plotted as the EW and the NS components taking the geometric mean. The highest $\mathrm{S}$-wave amplitude was used in the calculations before and after $2 \mathrm{~s}$ and $7 \mathrm{~s}$, respectively. The two ends of the data were multiplied with $10 \%$ cosine processor and the Konno\&Ohmachi factor was taken as 40. 


\section{Discussion And Conclusion}

In this study, aimed to determine soil amplification and dominant frequency characteristics of Izmir settlement area, generally, amplification values around alluvial soils are high at lower frequencies and around compact soils have low amplifications at high frequencies. Within this study, SSR amplification values are calculated for all IzmirNET stations. From the stations located on four different geological units, the results on the alluviums are shown in figure 4, the ones on the Miocene aged sandstones, the mudstones are shown in figure 5, the ones on the Miocene aged volcanic rocks and andesites are shown in figure 6, the ones on the Paleocene flysch and limestone are shown in figure 7.
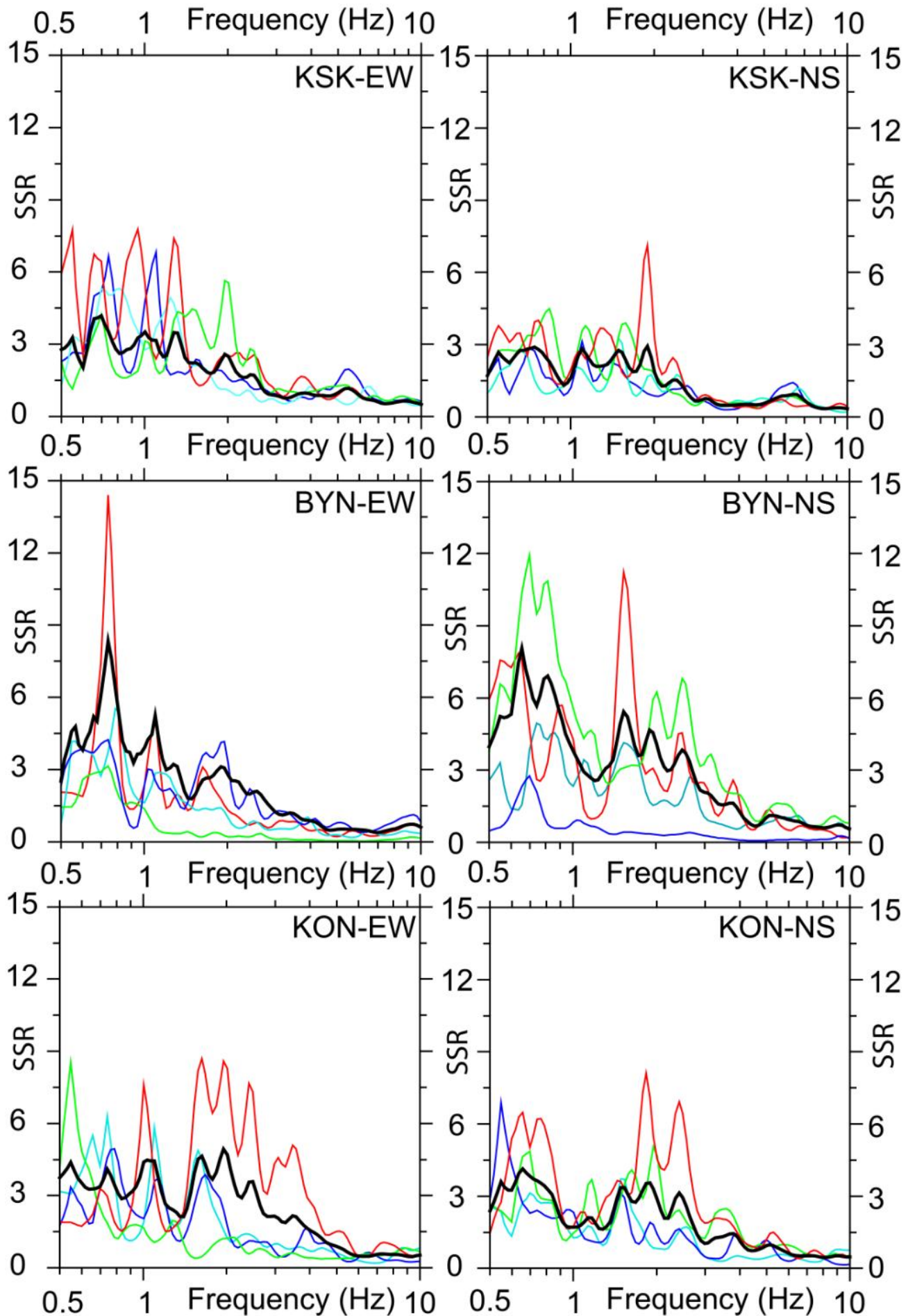

Fig. 4: Soil amplification predicted at site BYN, KON and KSK using earthquake data for alluvium soft soil. The black curve illustrates average amplification calculated from SSR technique. 
In the created graphics, left column symbolizes EW while the right one is NS. The thick black lines in all drawn graphics are the arithmetic mean curve. Upon looking at all the SSR graphics, it can be seen that dominant ground frequencies in IzmirNET have changed from $0.5 \mathrm{~Hz}$ to $2.5 \mathrm{~Hz}$ and the average amplifications have changed from 2 to 8 . As it was expected, high amplifications were observed at low frequencies at KSK, $\mathrm{BYN}$ and KON stations. The average dominant frequency and amplifications for these three stations on the alluvial ground are $0.8 \mathrm{~Hz}, 8$; respectively. The average dominant frequency and amplifications in KYN and URL stations located on sandstones and mudstones are $1.5 \mathrm{~Hz}, 6$; respectively. The amplifications values in the PNR station are less than the others and the amplification is about 3. In the YSL station, the dominant frequency is $2 \mathrm{~Hz}$ and the amplifications value is about 4. At BUC and BYR stations on the most compact units, the lowest amplifications were observed as it was expected. Figure 8 shows the variation of the amplification values calculated in IzmirNET strong motion stations according to the frequencies. High amplifications ranging from 6 to 8 were observed at low frequencies in the vicinity of Izmir Bay. The lower amplifications observed at higher frequencies are the values of the base rock. Attention should be paid to constructions which are observed in loose grounds and which will be carried out in these most dangerous amplifications.

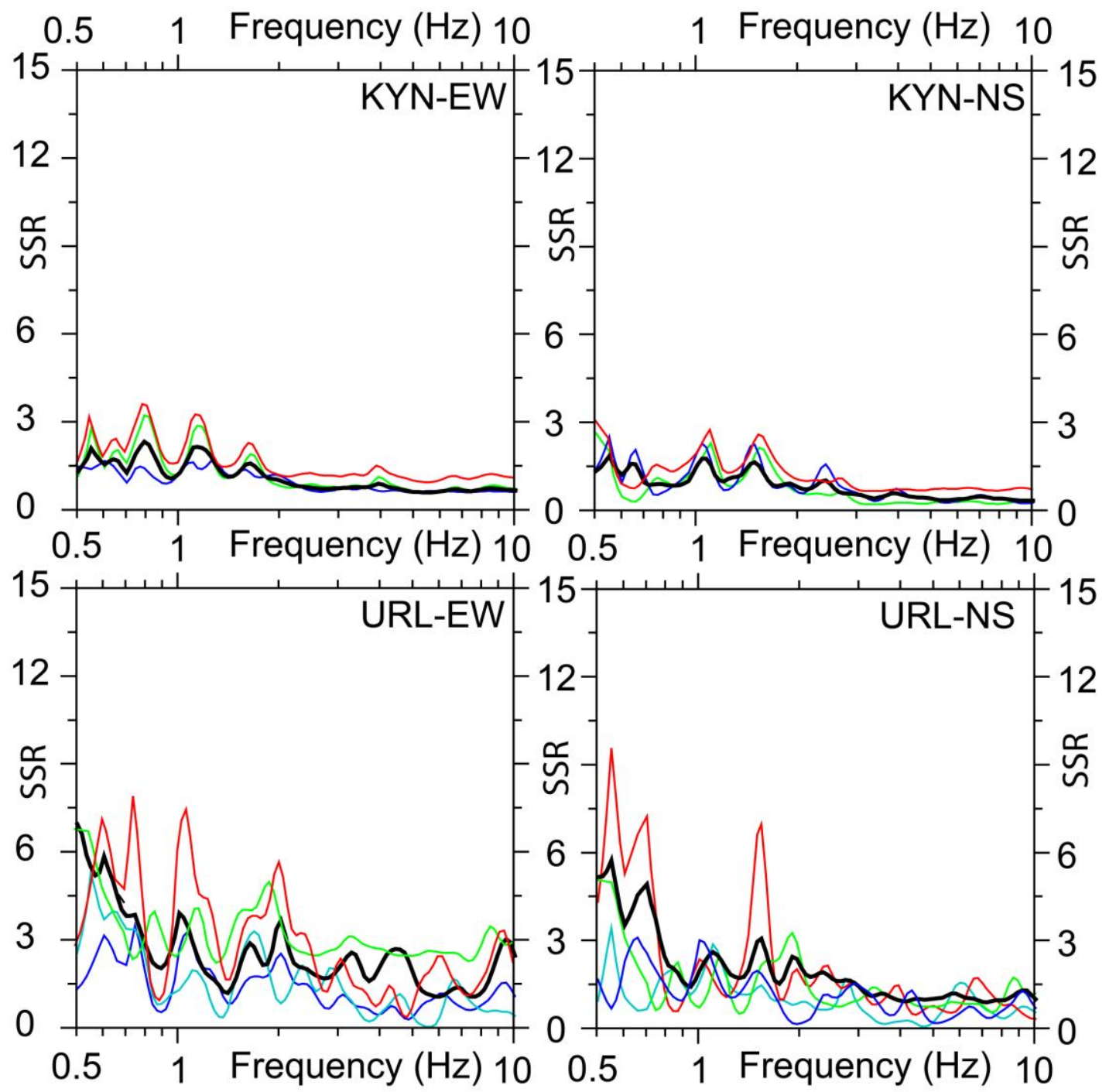

Fig. 5: Soil amplification predicted at site KYN and URL using earthquake data for sandstone and mudstone. The black curve illustrates average amplification calculated from SSR technique. 

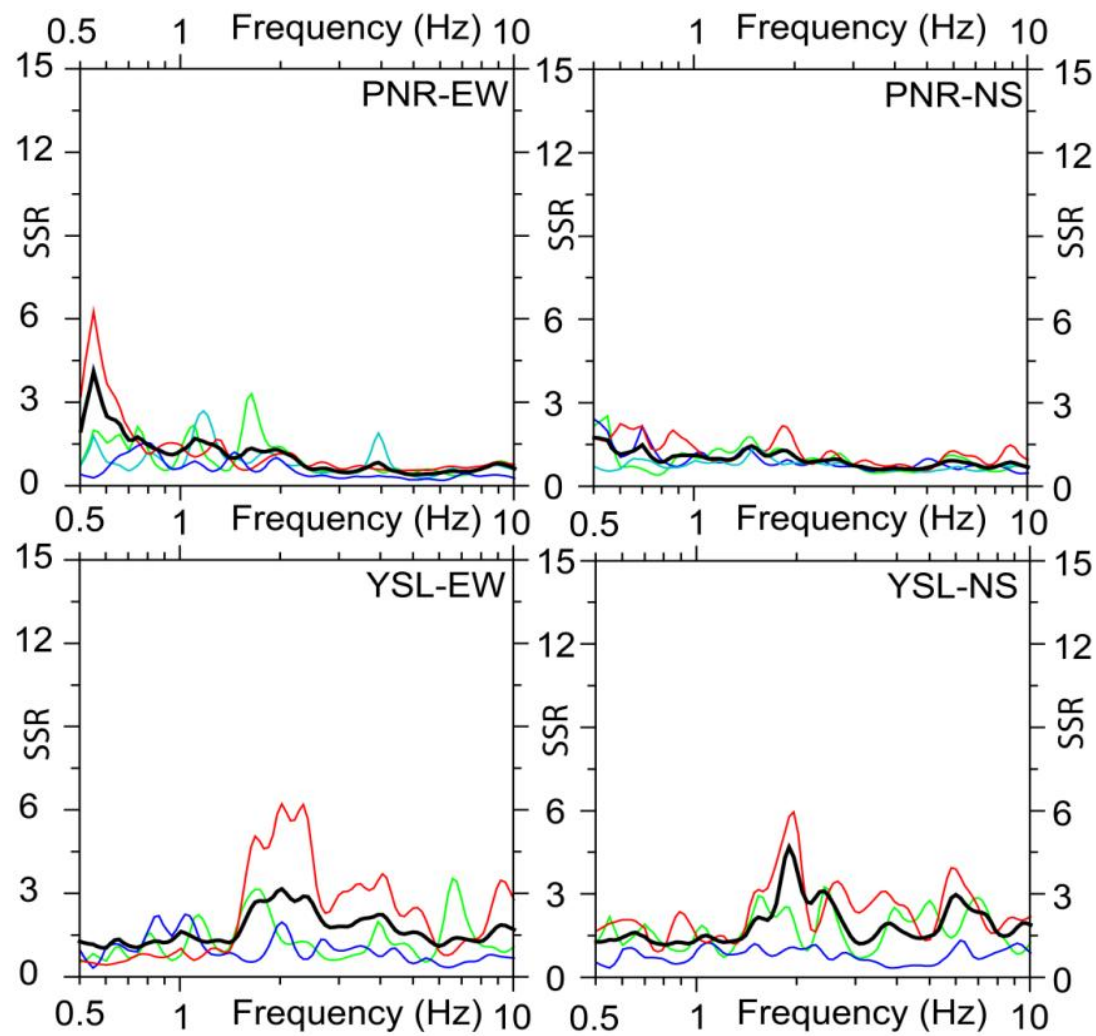

Fig. 6: Soil amplification predicted at site PNR and YSL using earthquake data for volcanic units. The black curve illustrates average amplification calculated from SSR technique.

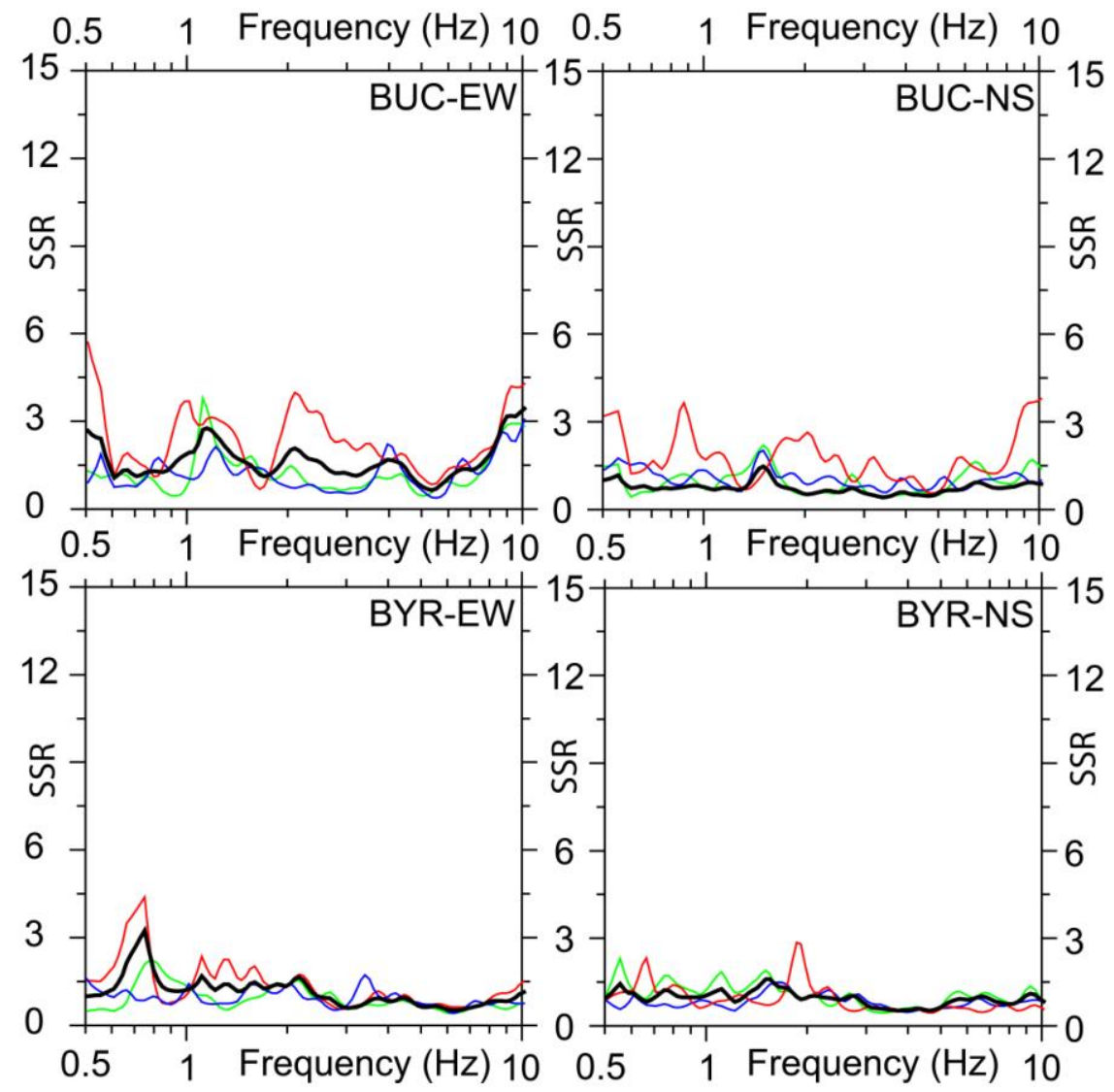

Fig. 7: Soil amplification predicted at site BUC and BYR using earthquake data for flysch and limestone. The black curve illustrates average amplification calculated from SSR technique. 

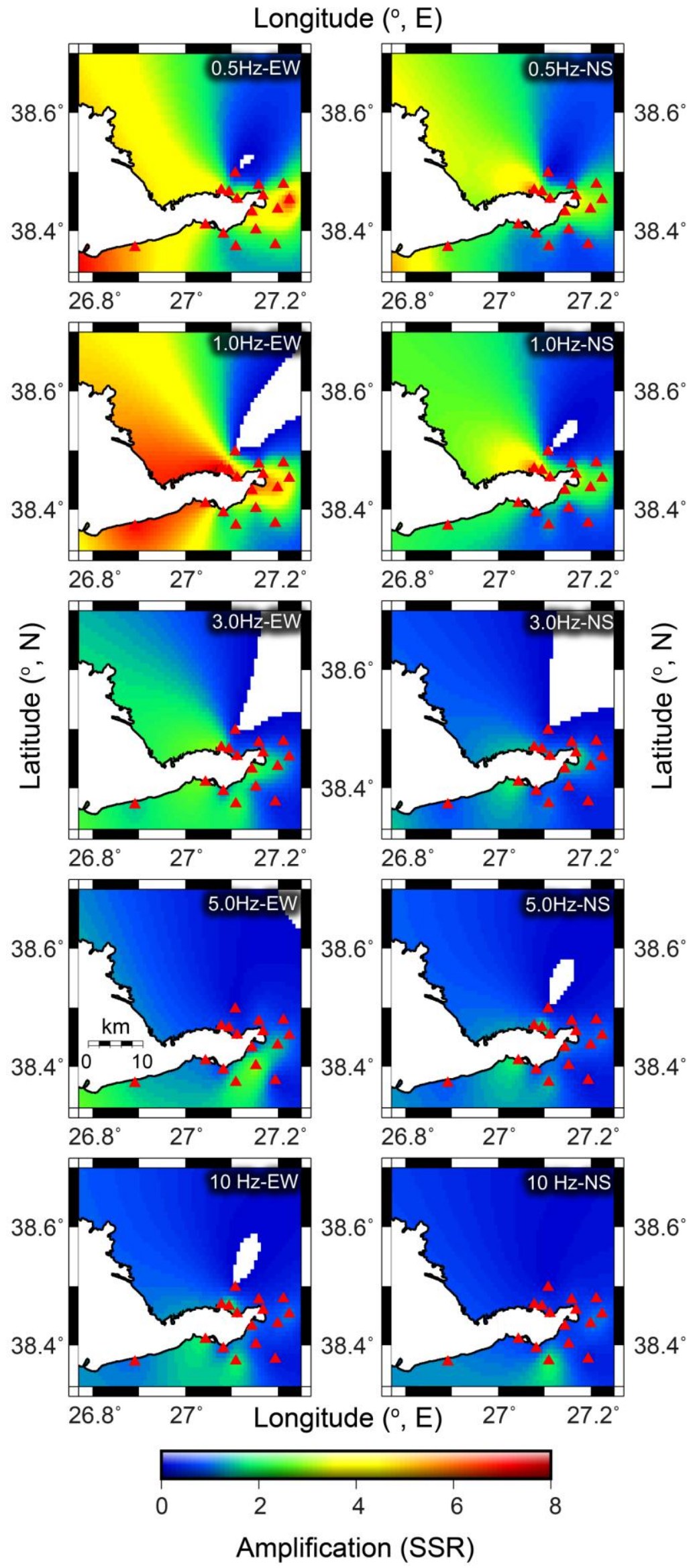

Fig. 8: Horizontal variation of amplification values for frequencies $0.5,1.0,3.0,5.0$ and $10.0 \mathrm{~Hz}$. 
In summary, dominant frequency values at stations represented by BLC, BOS, BYN, GZL, KON, KSK, MVS gave high peaks at low frequencies. These stations can shed light on the constructions on the young alluvial units in this area as they show amplifications at high rates during the earthquake. These results are not the arithmetic average of a single earthquake; it is average of five earthquakes selected according to the certain criteria. As a result, it has been determined that the earthquake effect can be increased 4-5 times depending on the distance, size and depth of earthquake in residential areas near URL, KSK, BYN and KON stations (Fig. 8).

\section{Acknowledgements}

The earthquake data was obtained from AFAD (Ankara-Turkey). Geopsy algorithm was used the calculation of the Standard Spectral Ratio (SSR) and Horizontal to vertical spectral ratio (HVSR). Calculations were conducted in SeismoLab (Seismological Laboratory) belongs to the Department of Geophysics of Dokuz Eylul University. Some images are created using GMT algorithm [11].

\section{References}

[1]. E. Gök and O. Polat, Strong-Ground Motion Earthquake Station Network of Izmir : IzmirNET, Süleyman Demirel Üniversitesi, Fen Bilimleri Enstitüsü Dergisi.;15(3), 2011, 233-243.

[2]. O. Polat, U. Ceken, T. Uran, E. Gok, N. Yilmaz, M. Beyhan, N. Koc, B. Arslan, D. Yilmaz and M. Utku, IzmirNet: A strongmotion Network in Metropolitan Izmir, Western Anatolia, Turkey. Seismological Research Letters, 80(5), 2009, 831-838.

[3]. B. Uzel, H. Sözbilir and C. Ozkaymak, Neotectonic Evolution of an Actively Growing Superimposed Basin in Western Anatolia: The Inner Bay of İzmir,Turkey. Turkish Journal of Earth Sciences, 21, 2012, 439-471.

[4]. H. Sozbilir, B. Sari, B. Uzel, O. Sümer and S. Akkiraz, Tectonic implications of transtensional supradetachment basin development in an extension-parallel transfer zone: The Kocaçay Basin, western Anatolia, Turkey, Basin Research.;23(4), 2011, 423-48.

[5]. E. Gok, M. Kececioglu, U. Ceken and O, Polat, Estimation of Soil Transfer Functions of Izmirnet, DEU Mühendislik Fakultesi Muhendislik Bilimleri Dergisi, 14(41), 2012, 1-11.

[6]. E. Gok and O. Polat, An assessment of the microseismic activity and focal mechanisms of the Izmir (Smyrna) area from a new local network (IzmirNET), Tectonophysics, 635, 2014, 154-64.

[7]. E. Gok, FJ. Chávez-García and O. Polat, Effect of soil conditions on predicted ground motion: Case study from Western Anatolia, Turkey, Physics of the Earth and Planetary Interiors, 229, 2014, 88-97.

[8]. O. Emre, S. Ozalp, A. Doğan, V. Ozaksoy, C. Yildirim, F. Goktas, Izmir Yakin Cevresinin Diri Faylari ve Deprem Potansiyelleri, MadenTetkik ve Arama (MTA), Ankara; 2005.

[9]. JL. Chatelain. Guidelines for the Implementation of the H/V Spectral Ratio Technique on Guidelines. 2004. Available from: http://sesame-fp5.obs.ujf-grenoble.fr/index.htm\%0AParticipating

[10]. M. Wathelet, D. Jongmans, M. Ohrnberger, and S. Bonnefoy-Claudet, Array performances for ambient vibrations on a shallow structure and consequences over Vs inversion, Journal of Seismology, 12(1), 2008, 1-19.

[11]. P. Wessel and WHF. Smith. New, improved version of generic mapping tools released, Eos, Transactions American Geophysical Union, 79(47), 1998, 579-579. 